\title{
白血球エラスターゼの血清濃度上昇と相関を示す 臨床化学検查值の検索
}

\author{
永松 陽子* 島田 裕充 ${ }^{* *}$ 川島 信二*** 岡本 歌子* \\ 石崎 誠司 ${ }^{*} \quad$ 津田 裕子**** 岡田 芳男****
}

\section{Search for laboratory findings which well reflect elevation of leukocyte elastase in serum}

\author{
Yoko NAGAMATSU*, Hiromitsu SHIMADA**, Shinji KAWASHIMA***, \\ Utako OKAMOTO*, Seiji ISHIZAKI*, Yuko TSUDA****, Yoshio OKADA****
}

Key words: leukocyte elastase, leucine aminopeptidase, laboratory findings, synthetic substrate

In order to know the pathological significance of elastase (ELP) released from leukocytes in blood circulation, the laboratory findings which may have connection with high ELP level in sera were searched. ELP value was examined using frozen sera obtained from two laboratories (164 and 125 cases). The value determined using Suc-Ala-Tyr-Leu-Val-pNA remained unchanged by repeated freezing and thawing. The results obtained were as follows.

1) ELP level obtained in sera from healthy human blood (control) was $315 \pm 165 \mathrm{ng} / \mathrm{ml}$.

2 ) The value increased significantly in the patients sera which showed high value of leucine aminopeptidase (LAP), $\gamma$-GTP, GOT, GPT and ALP. ELP level in sera which LAP, $\gamma$-GTP, GOT, GPT and ALP showed high level was $1,370 \pm 825 \mathrm{ng} / \mathrm{m} l(\mathrm{n}=18)$, and it was $690 \pm 370 \mathrm{ng} / \mathrm{m} l(\mathrm{n}=15)$ in sera showing high level of only LAP and $\gamma$-GTP.

3 ) A correlation coefficient between ELP and LAP was 0.78 , and regression line was $y=$ $526 \mathrm{x}+130(\mathrm{x}=\mathrm{ELP}, \mu \mathrm{g} / \mathrm{m} l)$. The coefficient between ELP and $\gamma$-GTP was also 0.78 , but that between ELP and GOT (or GPT) was low ( $r=0.29,0.38)$.

* 神戸学院大学栄養学部生理 [干637 神戸市西区伊川谷有瀬], Department of Physiology, Faculty of Nutrition, Kobe-Gakuin University, Kobe, Japan.

** 大阪血清微生物研究所血液, Department of Haematology, Osaka Kessei Research Laboratory, Osaka, Japan.

*** 明舞中央病院中央検査室, Central Laboratory, Meimai-Chuo Hospital, Osaka, Japan.

**** 神戸学院大学薬学部薬化学, Department of Medical Chemistry, Faculty of Pharmaceutical Sciences, Kobe-Gakuin University, Kobe, Japan. 受付 : 1988. 1. 10. 受理 : 1988. 7. 15. 
4) ELP level in sera of patients with renal failure $(n=30)$ was $245 \pm 70 \mathrm{ng} / \mathrm{ml}$, and it was lower than that in control sera.

\section{はじめに}

近年, 白血病 ${ }^{11}$, 膵炎 ${ }^{2)}$, 腎疾患, SLE, リ ウマチ様関節炎等 3$)$ で, 白血球 エラスターゼ (ELP) が血清または関節液において免疫学的 に測定され，その濃度の上昇が病態に何等かの 影響を扣よぼしていることが示唆されている。 しかし，血清中の ELP 活性を測定した報告お よびその上昇を認めた研究は極めて少ない。本 報告では特定の病態と血清 ELP 值との関連を 研究することを目的とし, 疾患を限定せずに, できるだけ多くの血清について，特異的合成基 質で測定した ELP 值と, 種々の臨床化学検査 值との間で相関を示す因子, あるいは有意に ELP 高值を示す血清に共通する因子を求めた。

\section{I. 材料および方法}

臨床化学検查值の明らかな血清を二か所の検 查室から任意に収集し，ELP 值を測定するま で凍結保存した。健康成人から得たコントロー ル血清は，検査室の条件に近似させるため，採 血後 1 時間から 5 時間, $20^{\circ} \mathrm{C}$ と $37^{\circ} \mathrm{C}$ で放置 後，遠心分離して得た血清を使用した。このよ らな条件での放置では相互に有意差を認めなか ったので， 3 時間， $20^{\circ} \mathrm{C}$ の条件を採用した。 血清 ELP 值は Suc-Ala-Tyr-Leu-Val-pNA を 用いて測定 ${ }^{4)} し$ ，前報に従って換算した ${ }^{5)}$.

\section{II. 結果および考察}

二検查室より得た 164 例と 125 例の血清 $\mathrm{ELP}$ 值の平均值は $500 \pm 490 \mathrm{ng} / \mathrm{ml}$ で, コント

Table 1 Serum ELP levels of normal and abnormal groups in clinically important findings

\begin{tabular}{|c|c|c|}
\hline \multirow{2}{*}{ Findings } & \multicolumn{2}{|c|}{ Serum ELP $(\mathrm{ng} / \mathrm{m} l)$} \\
\hline & Normal group & abnormal group \\
\hline "CRP & $370 \pm 230$ & $515 \pm 285$ \\
\hline RA & $540 \pm 230$ & $* 315 \pm 280$ \\
\hline Blood sugar & $655 \pm 600$ & $770 \pm 710$ \\
\hline$\beta$-Lipoprotein & $625 \pm 515$ & $655 \pm 680$ \\
\hline Cholesterol & $710 \pm 515$ & $625 \pm 625$ \\
\hline Total lipids & $800 \pm 655$ & $800 \pm 770$ \\
\hline Blood amylase & $685 \pm 655$ & $770 \pm 710$ \\
\hline $\mathrm{A} / \mathrm{G}$ ratio (low) & $660 \pm 640$ & $770 \pm 710$ \\
\hline$" \mathrm{LDH}$ & $655 \pm 600$ & $770 \pm 515$ \\
\hline **ALP & $570 \pm 485$ & $855 \pm 685$ \\
\hline$* * * \mathrm{GOT}$ & $485 \pm 425$ & $1140 \pm 710$ \\
\hline$* * * \mathrm{GPT}$ & $425 \pm 285$ & $1110 \pm 710$ \\
\hline$* * * \gamma-\mathrm{GTP}$ & $370 \pm 230$ & $1025 \pm 685$ \\
\hline$* * *$ LAP & $370 \pm 170$ & $1085 \pm 685$ \\
\hline Cholinesterase (low) & $685 \pm 625$ & $855 \pm 570$ \\
\hline Creatine & $685 \pm 600$ & $* * * 285 \pm 140$ \\
\hline NPN & $740 \pm 625$ & $* * * 380 \pm 370$ \\
\hline
\end{tabular}


Table 2 Correlaton between ELP and important enzyme in serum

\begin{tabular}{c|l|c|l}
\hline $\mathrm{x}$ & \multicolumn{1}{|c|}{$\mathrm{y}$} & $\mathrm{r}$ & $\mathrm{y}=\mathrm{ax}+\mathrm{b}$ \\
\hline ELP & LAP & 0.78 & $\mathrm{y}=526 \mathrm{x}+130$ \\
ELP & $\gamma$-GTP & 0.78 & $\mathrm{y}=539 \mathrm{x}-12$ \\
ELP & GOT & 0.29 & $\mathrm{y}=53 \mathrm{x}+28$ \\
ELP & GPT & 0.38 & $\mathrm{y}=80 \mathrm{x}+29$ \\
ELP & ALP & 0.31 & $\mathrm{y}=14 \mathrm{x}+11$ \\
\hline
\end{tabular}

$\mathrm{x}(\mathrm{ELP}): \mu \mathrm{g} / \mathrm{m} l$

ロール血清の ELP 值 $315 \pm 165 \mathrm{ng} / \mathrm{m} l$ との間 に有意の差を認めた $(\mathrm{p}<0.005)$ ， そこで表 1 に各臨床検查値ごとに正常值群と高值群（一部 低值群）に分類し，各々の血清 ELP 值を比較 してみた. GOT, GPT, $\gamma$-GTP, LAP 高值群 では正常値群の 2.4 倍から 3 倍近い值を示した $(\mathrm{p}<0.005)$ 。また，ALP， LDH，CRP の高値 群においても，血清 ELP 值は有意に高かっ た。一方, creatinine, NPN 高值群では逆に正 常値群より血清ELP 值は低< $(\mathrm{p}<0.0005)$ 両 高值群に抢いてはその他の因子の影響が強く反 映され, creatinine, NPN 高値は血清 ELP 值 上昇に全く影響していないと考兄られる。ま た，腎不全により血液透析を定期的に受けてい る患者（30 例）の透析直前の血清中の ELP 值 も $245 \pm 70 \mathrm{ng} / \mathrm{m} l$ と正常值よりもむしろ低く, このような腎不全に执いては血清 ELP 上昇例 はなかった。一方, 各種肝疾患の病態を反映し ている主たる血清酵素の異常は ELP 值の上昇 と相関関係を示した。

表 2 に ELP と血清酵素の相関係数と回帰直 線を示す。特に LAP, $\gamma$-GTP は ELP と高い 相関を示した。 また，289 例中，LAP， $\gamma$-GTP， GOT, GPT が正常である 40 例の ELP 值は $260 \pm 135 \mathrm{ng} / \mathrm{ml}$ と低く, 肝組織の異常と ELP 上昇の関係が示唆された。したがって, 種々の
疾患で血清または血漿 ELP 值の測定に際し て, 肝胆道系疾患の有無を考慮する必要があ る. ELP 上昇の機序として, 第一に炎症部位 に打ける白血球からの放出が考光られるが，そ れを CRP や RA の上昇と結びつけることは できなかった。しかし, 膵炎, 肝炎, 胃癌, 卵 巣癌, 白血病で血清 ELP の上昇例が多く, 炎 症部位に掓を白血球からの ELP 放出に加光 て網内系に打ける ELP-inhibitor complex のク リアランスの低下も考慮しなければならない。 診断の確定した症例について継続測定を行い， 血清 ELP 上昇の機序と病態との関係を明らか にすることが今後の課題である.

\section{文献}

1) Sterrenberg, L., Haak, H.L., Brommer, E.J.P., Nieuwenhuizen, W.: Evidence of fibrinogen breakdown by leukocyte enzymes in a patient with acute promyelocytic leukemia. Haemostasis, 15: 126 133, 1985.

2) Lasson, A., Balldin, C. and Ohlsson, K.: Leukocyte elastase $\alpha_{1}$-proteinase inhibitor complexes may diagnose pancreatic abscesses early. Scand. J. Gastroenterol., 21: 221 224, 1986.

3) Adeyemi, E.O., Hull, R.G., Chadwick, V.S., Hughes, G.R.V. and Hodgson, H.J.F.: Circulating human leukocyte elastase in rheumatoid arthritis. Rheumatol. Int., 6: 57 60, 1986.

4) Nagamatsu, Y., Okamoto, U., Tsuda, Y. and Okada, Y.: Human leukocyte elastase-like proteinase purified by affinity chromatography with Suc-L-Tyr-D-Leu-D-Val-pNA, and its identification with human spleen fibrinolytic proteinase. Thrombos. Haemstas., 51: 243 $247,1984$.

5 ) 永松陽子, 山本順一郎, 石崎誠司, 堀江 登, 岡本歌子, 飯泉久子, 津田裕子, 岡田芳男: 白 血球エラスターゼ扰よびカテプシン $\mathrm{G}$ の血漿, 血清, 白血球中濃度。血液と眽管, 19：1988. 